\title{
DOM PEDRO I OF BRAZIL AND IV OF PORTUGAL EPILEPSY AND PECULIAR BEHAVIOR
}

\author{
Marleide da Mota Gomes', Miguel Chalub²
}

\begin{abstract}
We present medical issues related to Dom Pedro de Alcântara Bragança e Bourbon (17981834), first Emperor of Brazil. This is made by means of narrative revision on historical facts starting from primary and secondary sources. Dom Pedro presented familiar incidence of epilepsy. His seizures were relatively benign and scattered, supposedly started at the age of 13: idiophatic epilepsy with generalized tonic-clonic seizures only or juvenile myoclonic epilepsy. He also had behavioral disorder characterized by hypersexuality, agitation and impulsiveness. It could have facilitated his opportunistic behavior necessary of daring to transgress the conservatism of the Portuguese crown, to create the constitutional monarchism in Brazil and in Portugal.
\end{abstract}

KEY WORDS: epilepsy, history, medicine , monarchy, Brazil, Portugal.

\begin{abstract}
Epilepsia e comportamento peculiar de Dom Pedro I do Brasil e IV de Portugal
RESUMO - Apresentamos aspectos médicos relacionadas a Dom Pedro de Alcântara Bragança e Bourbon (1798-1834), primeiro Imperador do Brasil. Isso é feito por meio de revisão narrativa sobre fatos históricos baseados em fontes primárias ou secundárias. Dom Pedro apresentou epilepsia de incidência familiar. Suas crises eram relativamente benignas e esparsas, de início provavelmente aos 13 anos: epilepsia idiopática generalizada com crises tônico-clônicas apenas ou epilepsia mioclônica juvenil. Ele também tinha transtorno do comportamento caracterizado por hipersexualidade, agitação e impulsividade. Isso pode ter facilitado seu comportamento oportunístico necessário para ousar a transgredir o conservadorismo da coroa portuguesa e criar o monarquismo constitucional no Brasil e em Portugal.
\end{abstract}

PALAVRAS-CHAVE: epilepsia, história, medicina, monarquia, Brasil, Portugal.

Dom Pedro, first Emperor of Brazil (1822-1831), and his family had a rich history of epilepsy. The Brazilian royal family dealt with it with sincerity and "any mystery about the disease in question, cited by the own victims of so high lineage", as remembers Rangel ${ }^{1}$. The coming of the Portuguese royal family to Brazil in 1808 defined a milestone between the colony and the country center of an empire. This arrival was also important for the progress of the nation, as the beginning of the national medical education and the foundation of the medical schools of Bahia, soon followed by that of Rio de Janeiro, now named Faculty of Medicine of Federal University of Rio de Janeiro ${ }^{2,3}$. A nomination made by Dom João (at the occasion, the regent prince) for this last school was of José Maria Bomtempo (1774-1843), Dom Pedro's physician for more than 20 years ${ }^{4,5}$. We present basic aspects of Dom Pedro's growing, social behavior, policies and lovers, and, finally, consider- ations on his epilepsy, and on his behavior diagnosed at the top of some existing reports.

\section{Growing of the prince and his inheritance}

Dom Pedro was born (1798) in Queluz/Portugal, in the same place where he died (1834), and several members of his family were important for the Portuguese and Brazilian history ${ }^{6-10}$. Dom Pedro had a grandmother with psychosis (D. Maria I - 1734-1816) ${ }^{7}$. One remembers that the English kingdom ally at the time of Dona Maria I also had an equally mentally ill monarch, Jorge $1 \mathrm{II}^{8}$. They had a common doctor, Dr. Willis. This was another link, beyond the political and commercial, to the two royal houses ${ }^{8}$. Regarding Dom João's personality, it was diametrically opposed to the one of Dom Pedro and Dona Carlota Joaquina: kind, conciliator, melancholic, and never leading to confrontations. Dom Pedro's mother was from the Spanish royal house, who was moved away 'Programa de Epilepsia do Instituto de Neurologia Deolindo Couto/Universidade Federal do Rio de Janeiro, Rio de Janeiro, Brazil
(UFRJ); ${ }^{2}$ Instituto de Psiquiatria/ UFRJ.

Received 31 October 2006, received in final form 7 May 2007. Accepted 15 May 2007.

Dra. Marleide da Mota Gomes - Instituto de Neurologia da UFRJ - Avenida Venceslau Braz 95 - 22290-140 Rio de Janeiro RJ - Brasil. E-mail:mmotagomes@acd.ufrj.br 
from her relatives for precocious marriage with the Portuguese prince Dom João. Dona Carlota Joaquina had as impressive trace, an extreme vivacity and she was a woman of many lovers, uneasy, intelligent, and of clear ambitions and political aggressiveness ${ }^{7}$. Regarding Dom Pedro, he arrived in Brazil with 9 years of age. He came with his family and great part of the Portuguese noblemen fleeing from the invading Napoleonic troop to Portugal. However, he was early adjusted to the habits of the new land. His basic formation was not as rudimentary as it was first assumed ${ }^{5}$. He did not limit himself to the humanistic and basic musical formation: he played several instruments and he was contumacious writer - "craze to write", besides, he became involved in unusual activities to the noblemen, as working with wood ${ }^{6}$. He was also a great horseman and seducer, mainly of the women who could be of any nationality or color ${ }^{5,6}$. He had many children from the two official marriages and several extramarital relationships, mainly with the Marchioness of Santos.

\section{Dom Pedro's epilepsy}

Dom Pedro epileptic seizures were predominantly of the generalized tonic-clonic type, of short duration, beginning of the public knowledge to the 13 years, and scattered, even with the hiatus of some years ${ }^{8}$.

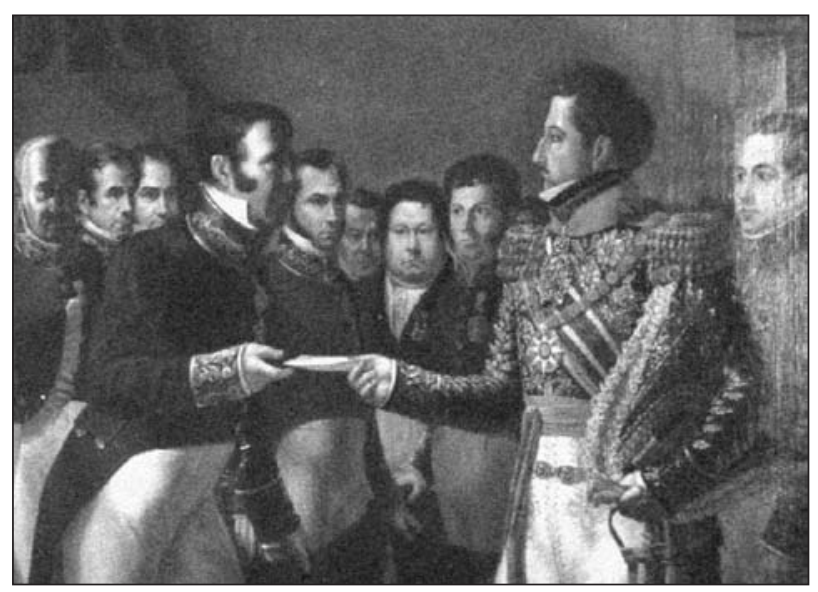

Figure. Dom Pedro I gives to Vicente Navarro de Andrade (Baron of Inhomirim) the decree of September, 18262,3 (allegory). It granted to the directors of the two Brazilian Schools of Medicine the attribution to confer the certificates to surgeons and practicing surgeons. This advance was so important for the Brazilian medical education history that some students at the time ordered to Araújo Porto Alegre the painting that today is held in the noble hall of the Faculdade de Medicina, in the Fundão Island, Rio de Janeiro ${ }^{2}$ (permission for the reproduction given by the Faculdade de Medicina do Rio de Janeiro administration).
Depositions - Apparently, this disclosure happened after the occurrence of successive seizures as the marquis of Valada told to the Aguiar, apud Souza5: "our adored prince had suffered in one day three successive attacks of accidents, suffering for the first time of the same disease of Sereníssima Senhora Infanta Dona Isabel Maria". Five years later, at the age of 18 , in 1816, he already had suffered six "severe" attacks ${ }^{1,10}$. One seizure was publicly witnessed in Dom João VI's birthday solemnities, on May 13, 1816, four hours p.m. ${ }^{1,5,10}$ when Dom Pedro de Alcântara was seen tumbling to the ground with one significant syncope, according to Macaulay ${ }^{10}$ : "Dom Pedro suddenly was bent down on his knees, with a livid face and looking straight ahead, foaming from the mouth, he started to convulse deliriously on the ground. The stunned spectators had observed the scene, while the assistants, in the way of the spasms of the prince, had carried him to a house in the neighborhoods; two hours later, although very tired, Dom Pedro was already recovered from the attack". It seems that in the beginning of the marriage with the princess Leopoldina the seizures had been more frequent: one after a month of her arrival, others at the end of November 1818, in August 1819 and January $1820^{\circ}$. He had a special sofa exactly, according to the princess, for use "when the prince had his attacks of nerves", apud Lustosa ${ }^{8}$. The Diário Fluminense of Rio de Janeiro Province, official newspaper, of June $5,1824^{11}$ communicated in the following day of the occurrence of a seizure: "We have the annoyance of announcing to our readers that His Majesty the Emperor was threatened yesterday of one of his old attacks ...for the interest that we all have in the Health of the August Gentleman, nevertheless, it is not threatening...". This was an official notice of a health fact with political repercussions that justified new information in the same Daily ${ }^{11}$ three days after: "His Majesty the Emperor after 5 years of interruption of the epileptic accidents that he was prone, he was again undertooke of a new seizure, on Friday the $4^{\text {th }}$ of the current month at 7 o'clock at night, of an accident of the same nature, but of little violence, he spent the night calmly, and he felt today in such good state that he got up and he Presided the Council. Imperial Paço of Boa Vista June 5, 1824 - Domingos Ribeiro do Guimarães Peixoto, general physician of the Imperial Chamber, Assistant of His Majesty the Emperor". This report so officially established was in a political context that weeks later generated the "furious announcement against the rebels of Pernambuco and the Military Commission decree to 
judge them" ${ }^{5}$. There is the report of another seizure in May 20,1830, this more lengthy ${ }^{1}$. This last seizure was described by the French diplomat Pontois, apud Souza 5: "L'empereur a eu, ce matin avant d'aller à la messe, une forte attaque d'epilepsie (...) il était occupé à ecrire en prenant une tasse de thé, lorsquíl tomba tout a coup à terre et demeura pendant $10 \mathrm{~min}$ utes sans conaissance". Souza ${ }^{5}$ continue telling that in the following day the diplomat did not find him anymore in the house, therefore he was totally recovered and he had already left. In another occasion, Souza ${ }^{5}$ says, the diplomat was received by the Emperor who informed to him that the "epileptic seizures was a thing without importance, and a disease that the house of Spain brings to his family, and he asked to Baron Antonini, who was present in the audience, if the Bourbons of Naples also suffered from that harm... he said that in the last nine years he had had only two attacks ...".

Etiology - On June 16, 1829, Dom Pedro had new problem of health ${ }^{1}$. Ten doctors had been congregated to deal with the case ${ }^{1}$. They had prescribed water of Vichi and muriate of iron, and Dr. Vicente Navarro de Andrade presented to the illustrious patient rules of health ${ }^{1}$. One must question if that crisis revealed more than the epilepsy, but another illness that worsened the Emperor's health already in decline. Pimentel ${ }^{12}$ mentions that the Emperor began to have violent nephritic colic in 1828. To favor this diagnostic hypothesis to the health problem of June 16,1829 , there is a report of the French ambassador who mentioned the occurred seizures of May 29, 1830: "... L' empereur a eu, ce matin... une forte attaque d'epilepsie, maladie donc il est malheureusement atteint depuis longtemps, mais dont le retour ne s'était pas fait sentir avec une pareille violence, depuis 6 ans.." ${ }^{1}$. One of the Emperor's letters to the Marchioness of Santos can suggest a focal seizures (positive phenomenon) preceded by numbness that can be of some etiologies. Dom Pedro describes "I did not pass very well, therefore waking up with an numb arm, later I felt tremble the finger on my left-hand which scared me to the point that I woke up with a tremor, later I evacuated, and now I am perfectly well, and to determination for everything..." ${ }^{13}$. Would be this the manifestation of myoclonic seizure that could be confused with a focal epileptic seizure $?^{14}$. Less probably, a type of secondary seizures to some illness related to his life of risk, as a syphilitic vasculite - focal epilepsy with posterior generalization? Or related to the brightisme and atherosclerosis that Pimentel ${ }^{12}$ suggested when describing the autopsy made in the corpse of the monarch in 1834 , consumed by the tuberculosis? We can not discard these secondary etiological possibilities, however with the genetic predisposition for seizures of any etiology as it happened in some members of Dom Pedro's family. Dom Pedro's epileptic familiar predisposition was recognized: "during the entire life, from intermittent form, Dom Pedro and almost all his brothers would suffer more or less violent epileptic attacks" ${ }^{8}$. Souza ${ }^{5}$ concluded that the majority of the members of the royal family had nervous illnesses, and of convulsive attacks few had escaped. Macaulay ${ }^{10}$ confirms this familiar incidence: "Except for the common inheritance of epilepsy, Dom Pedro seems to have escaped from the multiplicity of illnesses that afflicted his brothers..." It seems that Dona Leopoldina was not previously aware of the epileptic condition of his husband Dom Pedro, although this situation was not strange to her, because his brother, the Austrian heir prince Ferdinand was also a person with epilepsy, but in contrast to Dom Pedro I, until his 23 years, he still does not demonstrate interest for women nor he had similar general behavior ${ }^{10}$. The inheritance of the Dom Pedro epilepsy was transmitted to some of his children and grandchildren ${ }^{1,15}$. The Papal Nuncio credited at the court linked the "harm of the epilepsy or caduco harm that frequently is subject His Highness the royal prince (D. Pedro) to the Rio de Janeiro unfavorable weather" ${ }^{\prime 16}$.

Diagnosis - At the beginning of the XIX century, it predominated in the European Medicine the seizures classification of grand mal and petit mal. This last one was related to the manifestations of a great variety of attacks without the convulsive characteristics of the grand mal, beyond vertigos ${ }^{17,18}$. Thus, at this time, the absences and myoclonies could only be recognized as incomplete manifestations of epilepsy [If Dom Pedro would have absence or myoclonic seizures, this would collaborate with specific classification in juvenile myoclonic epilepsy or juvenile absence epilepsy. These manifestations could not be recognized in the remaining reports and does not authorize us to prioritize these diagnosis, although we can not reject them. Amongst the focal seizures with subsequent generalization, we have to remember the focal epilepsy of the temporal lobe, the most common adult focal epilepsy. It can express besides generalized tonic-clonic seizures, starings and automatisms, as some situations reported by Souza in Dom Pedro ${ }^{5}$. However, this type of epilepsy frequently does not have a good prognosis as the one of the Emperor]. Souza ${ }^{5}$ makes suggestive remarks about 
other types of Dom Pedro seizures: "It was his heavy nervous inheritance to favor similar manifestations that went since the sudden and brutal attack, inside the classic picture of loss of consciousness, fall and contortions... until the equivalent of the absences and vertigos". Souza ${ }^{5}$ tells one of his possible escapes of consciousness as to climb a wall of a fortress and to defecate squatting in front of a troop in parade pressed for the intestinal urgency, report that can not be truthful, and other similar reports of lapses of modesty and composure. One remembers that the idiopathic epilepsy with generalized seizures and varied phenotypes beginning in the adolescence regarding the clinical point of view can be unfolded in three types: juvenile absence epilepsy, juvenile myoclonic epilepsy and epilepsy with generalized tonicclonic seizures ${ }^{19}$. Still today, it is difficult to differentiate them, being the most correct to keep the diagnosis taking in account the predominant type of seizures ${ }^{14}$. Concluding, we consider more appropriate the third diagnosis for the Emperor's epilepsy, although we do not reject the second, juvenile myoclonic epilepsy. The multiple epilepsy seizures in the royal family permit to consider its hereditariness. In these cases, a reasonable interpretation for the clinical diversity is that many genes of epilepsy susceptibility exist, as also modifiers genes that in different populations converge in a lesser number of common phenotypes ${ }^{20}$. One second possibility of inheritance is the monogenic related to the heterogeneous group of the generalized idiopathic epilepsy [Dom Pedro I's some children seizures remember a syndrome of recent classification, generalized epilepsy with febrile seizures plus that is an umbrella for many other syndromes that share causative genes. It encompass (in some individuals and some combinations) not complicated febrile convulsions, febrile convulsions that persist beyond infan$c y$, afebrile seizures generalized tonic-clonic, atonic absence, myoclonie, seizures and epileptic seizures of temporal lobe ${ }^{20}$. Kulmann ${ }^{20}$ remembers this notable variability, consistent with a strong effect of modifiers factors when one only gene of "dominant" epilepsy is transmitted with high penetrance]. We also comment the acute cerebral insults and "nervousness" confused as epilepsy, as frequently occurred in the Portuguese royal family ${ }^{1,21}$.

Treatment - At the time, the treatment for the symptomatic or primary epileptic seizures was inefficacious. Dom Pedro was aware of these limitations. Lamego ${ }^{9}$ affirms that Dom Pedro "Sincerely, he did not believe in the Medicine at the time - then maybe, he did not submit himself to the precepts and "réci- pes" of the professionals who surrounded him" ${ }^{\prime \prime}$ Although, there is Dom Pedro's deposition that "..during the space of six years he prevented them (seizures) from happening thanks to a medicine brought from France and offered by the count of Gestas", apud Souza 5 .

\section{Dom Pedro's behavior}

To discriminate a posteriori the Pedro I behavior disorder type and its risk factors are not an easy task. The etiological possibilities may coexist and we will unfold them: environmental, of the growing of a prince and Gentleman in a disaggregated family and in a city in formation; or organic, of the genetic determinism of the neuropsychiatry disorders of the houses of Bragança, Portuguese, and Bourbon, Spanish. In the first class it exists what some people call power neurosis and what Lacassagne, apud Lamego ${ }^{9}$ called "caesaritis". Effectively, the heir prince was a precocious child and he had always the necessity to keep himself occupied, to vary toys often, to mount the horse, to give bath or fix the horseshoe on the horse, as Souza remembers ${ }^{5}$. However, he held great ability and tenacity to working with wood, for instance $^{5}$. The music was also very important to him, and he spent too much time with it, certainly because of the same of his father's propensity ${ }^{5}$. His multiple activities may be exemplified as it follows in a typical day: he woke up at five/six in the morning and the day unfolded in activities such as attending the Mass followed by administrative, politics, domestic, artistic and loving activities ${ }^{8}$. He presented variations of the mood and aggressiveness that were frequently followed by attitudes of reconciliation and much charm. He himself feared that his anxious state could be a precipitant factor of "accident", as he told in a letter to Marchioness of Santos of August $4^{\text {th }}$, 1825: "... as my affliction today has been so strong that I feel my nerves so affected that I fear some accident" ${ }^{13}$. He did not present the so called epileptic personality mainly found in patients with temporal lobe epilepsy with characteristics such as circumstantiality, dependence, seriousness and fatalism $^{22}$. Dr. José Maria Bomtempo mentioned his "extreme nervous mobility" 5 . Possibly, K. Schneider could described him as a hyperthymic. He considered this term better than "constitutional agitation" or "mania constitution" previously proposed by Kraepelin, apud Felino ${ }^{23}$. Souza ${ }^{5}$ comments "In a man so generously endowed, did not have only the grain of madness necessary to surpass the mediocrity: the traces and signs of psychic disorders that affected his sensibility and the superior abilities of spirit were add- 
ed". These mentioned signs would be related to the epilepsy or comorbidity such as an extreme hyperthymia? We also remember the impression of Dr. Casanova, doctor of the family of Dona Amélia, the second wife of Dom Pedro, expressed to José Bonifácio: "the Emperor has gone mad; if somebody comes to tell me that he walks throwing stones in the streets, it would not be a surprise to me", apud Lustosa ${ }^{8}$. Another deposition of that time of the marquis of Barbacena points to the same way: "One of His Majesty Imperial uncle-grandfathers finished his days in a jail in Cintra. His Imperial Majesty may finish His in some jail in Minas (Gerais), considered crazy: and in reality, only a crazy man sacrifice the interests of a nation, of his family and of the royalty in general, to the whims and seduction of servants" ${ }^{8}$. Several other reports about Dom Pedro remember his agitation, impulsive personality, willful and voluble nature ${ }^{8}$. He always remained himself very busy with multiple tasks and it exists reports of episodes that he looked for opportunities to awake his family at dawn with rifle hunting detonations ${ }^{8}$. We stand out his parsimony in the ingestion of alcoholic beverage. According to Lovell Badcock, apud Macaulay ${ }^{10}$, at the end of his life, Dom Pedro "was well behaved and a conciliatory spirit; he was rigorously abstemious, drinking only water and taking a cup of wine only as a greeting to some foreigner". There are reports linking a type of generalized epileptic seizures, some cases of patients with juvenile myoclonic epilepsy, to behavior characteristics that can be attractive, but unstable, suggestible and uncertain, with immature personality, resulting frequently in inadequate social adjustment related to functional deficiency of the frontal lobe ${ }^{24}$. Trimble quoted Tellenbach, apud Besag ${ }^{24}$, describes some of the features of the patients with juvenile myoclonic epilepsy as "impressionability, unreliability, instability, a tendency to extremes which is difficult to describe, a sentimental, sensitive personality continuously diverted by external events, whose development never matures into a harmonious personality." This relation can be multicausal and not necessarily tied only with the mentioned epilepsy. Even more, Dom Pedro may have had a epilepsy comorbidity such as the attention deficit hyperactivity disorder (ADHD). The principal characteristics of ADHD are inattention, hyperactivity, and impulsivity in different combinations. These symptoms appear early in a child's life (DSM-IV) ${ }^{25}$. There is the predominantly hyperactive-impulsive type that does not show significant inattention what seems to be the case of Dom Pedro. Although, there is also suggestive report of attention deficit because of his incapacity to con- centrate in readings for his education, in spite of the existence of others, that points out the contrary: his careful and attentive work with wood ${ }^{5}$. The hypothesis of the comorbidity of the ADHD in the Emperor, au grand complet, may be one of his infancy / youth and less of his adulthood. Not all patients with ADHD keep the symptoms until the adult life. Apparently, Friar Arrábida, his tutor, fought since early against the "defiance of the intelligent boy, but distracted, curious, but idle, sympathetic, but disobedient..." according to Souza ${ }^{5}$. The hippomania diagnostic hypothesis, more specifically of hyperthymic personality seems, also to be adequate for the association of extreme energy (agitation), extreme feelings of importance of ego (grandiosities), extreme interest in sex (hypersexuality) and little sleep, as also distraction and behavior of high risk as some reports suggest to exist in the personage. Regarding the sexuality, he was extreme, exaggerated, excessive of lasciviousness almost without pause, according to Souza ${ }^{5}$. To stand out, his excellence as father, as much for his many bastard as the legitimate children, despite the low quality as husband to Dona Leopoldina, besides the military competency. He led the progressive constitutionalists and defeated the authoritarian absolutists headed by his brother Dom Miguel ${ }^{5}$ who had troops in larger number ${ }^{9,10}$. In the public domain, because the constraints of policies imposed by the Brazilians on one side, and Portuguese on the other, he proclaimed during the trip between São Paulo and Rio de Janeiro, on the banks of the Ipiranga River, in São Paulo, the Brazilian Independence from Portugal, on September 7, 1822. He was also a recognized politician when fighting for his thrones, but abdicated them in favor of his son Dom Pedro II, in Brazil, and of his daughter Dom Maria II, in Portugal. Dona Carlota Joaquina presented with the male children similar behavioral aspects.

\section{Dom Pedro's health decay}

At the end of Dom Pedro's stay in Brazil, and already in Europe, he had other complaints. With 31 years of age, he had signals of physical decline that could not be ignored, being the most disturbing for him the reduction of his sexual power. Before, there were mainly his epilepsy and renal calculus, as Macaulay relates ${ }^{10}$. In this occasion, he was emotive, more sensitive ${ }^{5}$. His decline would be related to his intense and dangerous life, that predisposed him to the tuberculosis and some accidents secondary to falls from horses. However, in advanced state of the disease that consumed him there is report of fevers, tremors, pains in the chest and edemas in the 
feet ${ }^{10}$. At this time, his physical debility in general was registered: "... the tremor hindered him to write his personal letters of own fist, as he was accustomed to do..." ${ }^{10}$. Already in France, the crisis of renal calculus had become more frequent, what Macaulay ${ }^{10}$ speculate to having been due to the change to the French diet. His end was placid and in the bed, but his autopsy ${ }^{26}$ disclosed how much the tuberculosis consumed him, in a chain of "pathological guns", as the arteriosclerosis and the brightisme, as Pimentel ${ }^{12}$ speculated. Pimentel ${ }^{12}$ did not value the epilepsy in the court of Pedro IV, in contrast to some Dom Pedro I's biographers, in Brazil. However, as it can be inferred, much more than a germ and calculus abased the sovereign's body, as Dom Pedro himself in letter to their children of June $15,1834^{21}$ affirmed: "as I spoke to you about health that I disdained a lot...".

Acknowledgments - We acknowledge the collaboration of the staff for the consultation of books, periodicals and documents: of the libraries (Nacional, of the Academia Brasileira de Letras, Real Gabinete Português de Leitura, of the Instituto de Filosofia e Ciências Sociais da UFRJ, of the Faculdade de Letras da UFRJ) and of the Imperial Museu - Instituto do Patrimônio Histórico e Artístico Nacional - Ministério da Cultura (Archives and Library). We also acknowledge the Faculdade de Medicina da UFRJ administration for allowing the publication of the painting reproduction.

\section{REFERENCES}

1. Rangel A. O mal sagrado. In Trasanteontem (Episódios e relatos históricos). São Paulo: Livraria Martins Editora, 1943:43-69.

2. Vargas SSM, Valladares AF, Gomes MM. Direções e aspectos políticoadministrativos. In Gomes MM, Vargas SSM, Valladares AF (org.). A faculdade de medicina primaz do Rio de Janeiro em dois dos cinco séculos de história do Brasil. São Paulo: Editora Atheneu, 2001:3-24.

3. Casa de Oswaldo Cruz / Fiocruz. Dicionário Histórico-Biográfico das Ciências da Saúde no Brasil (1832-1930). Escola Anatômica, Cirúrgica e Médica do Rio de Janeiro http:/ / www.dichistoriasaude.coc.fiocruz. br/iah/P/verbetes/escancimerj.htm (09/03/2006).

4. Gomes MM, Halfoun VLRC. Ciências clínicas e populacionais. In Go- mes MM, Vargas SSM, Valladares AF (org.). A faculdade de medicina primaz do Rio de Janeiro em dois dos cinco séculos de história do Brasil. São Paulo: Editora Atheneu, 2001:81-82.

5. Souza OT. História dos fundadores do império do Brasil: a vida de Dom Pedro I. 3.Ed. Rio de Janeiro: Livraria José Olympio, 1957: 67, 68, 71, 73, $74,75,79,80,81,83,100,116,124,130,133,609-613,618$.

6. Calmon P. O rei cavaleiro. 3.Ed. São Paulo: Edição Saraiva, s/d: 17, 35, $39,41$.

7. Cheke M. Carlota Joaquina (A rainha intrigante). Rio de Janeiro: Livraria José Olympio Editora, 1949: 12, 14, 16, 209, 215.

8. Lustosa I. Dom Pedro I: um herói sem nenhum caráter. São Paulo: Companhia das Letras, 2006;26:71-73.

9. Lamego L. Dom Pedro I, herói e enfermo. Rio de Janeiro: Livraria Editora Zélio Valverde, 1939: 17, 44, 45, 47, 54, 111, 117, 133-138, 141, 141,178179 .

10. Macaulay N. Dom Pedro: a luta pela liberdade no Brasil e em Portugal, 1798-1834. Tradução André Villalobos. Rio de Janeiro: Record, 1993: 17, $53,64,75,82,84,89,134-135,137,197,229,270,299,318,336$.

11. Império do Brasil. Diário Fluminense. 5 de junho de 1824;6(126):525; 8 de junho de 1824;6(127):529.

12. Pimentel A. A corte de Dom Pedro IV. 2.Ed. Lisboa: Guimarães \& $C^{a}$ Editores, 1914: 13, 213, 224, 258, 259.

13. Rangel A. Marginados: anotações às cartas de Dom Pedro I a D. Domitila. Rio de Janeiro: Conselho Federal de Cultura e Arquivo Nacional, 1974: 71, 459, 461.

14. Salas-Puig J, Calleja S, Jimenez L, Gonzalez-Delgado M. Juvenile myoclonic epilepsy. Rev Neurol 2001;32:957-961.

15. Maul C. A vida da condessa de Iguassu. Rio de Janeiro: Valverde, 1942: 120.

16. Santos LC Filho. Patologia e terapêutica. In História geral da medicina brasileira. São Paulo: Hucitec EDUSP, 1991;1: 167, 184; 2: 47-49, 181326.

17. Eadie MJ. The epileptology of Theodore Herpin (1799-1865). Epilepsia 2002;43:1256-1261.

18. Temkin O. The nineteenth century (1800-1861). In The falling sickness: a history of epilepsy from the Greeks to the beginnings of Modern Neurology. 2.Ed. Baltimore: Johns Hopkins University Press, 1971:255-277.

19. Gomes MM. Epilepsia segundo a maturação e o envelhecimento cerebral subjacente. J Epilepsy Clin Neurophysiol 2003;9:227-234.

20. Kullmann DM. Genetics of epilepsy. J Neurol Neurosurg Psychiatry 2002;73:32-35

21. Arquivo Museu Imperial. II-POB, doc 3247, 04.05.1827, PI.B.m; m.100 doc. $4875,15.06 .1834$

22. Fizman A, Gomes MM. A interface entre epilepsia e psiquiatria. Braz J Epilepsy and Clinical Neurophysiology 2001;7:55-67.

23. Feline A. Hyperthymic disorders. Encephale 1993;19:103-107.

24. Besag FM. Behavioral aspects of pediatric epilepsy syndromes. Epilepsy Behav 2004;5(Suppl 1):S3-S13.

25. DSM-4. Manual diagnóstico e estatístico de transtornos mentais. Trad por Dayse Batista. 4.Ed. Porto Alegre: Artes Médicas, 1995.

26. Dantas J. Autópsias de reis. In Figuras de ontem e de hoje. Porto: Livraria Chardron de Lelo \& Irmão Ed., 1914:145-151. 